\title{
PERILAKU BISNIS MUSLIMAH : MUSLIMAH BERKELUARGA ANGGOTA IWAPI DI KOTA SURABAYA 1 I
}

\author{
Sesha Ayu Permatasari \\ Mahasiswa Program Studi S1 Ekonomi Islam Fakultas Ekonomi dan Bisnis Universitas Airlangga \\ Email : Seshaayu@gmail.com \\ Muhammad Nafik H.R \\ Departemen Ekonomi Syariah-Fakultas Ekonomi dan Bisnis-Universitas Airlangga \\ Email : Manhard999@yahoo.com
}

\begin{abstract}
:
The purpose of this research is to know whether the business behavior of a Muslim family of IWAPI members in Surabaya in accordance with the teachings of Islam. This study used a qualitative approach explanatory case studies. Data collection techniques using in-depth interviews, interviews, participant observation and documentation.

In this study, the behavior of the Muslim business in terms of aspects of motivation, commitment to family, barriers experienced, responsibilities and activities as well as adopting a business strategy which includes four properties of the Prophet namely: Siddiq, Trustworthy, Fatonah, Sermons. Results of this study are doing business is not forbidden in Islam as long as it does not ignore the views of the main task of a Muslim as a housewife. Business motivation of housewives is gain a flexible time management so as to enable a balance between the obligations of housewives and business. Thus a Muslim is able to prove that a Muslim could succeed as a wife, IWAPI members and businesswomen.
\end{abstract}

keywords: IWAPI, motivation, behavior, responsibility

\section{PENDAHULUAN}

Latar Belakang

Bisnis dalam Al-Quran berarti

Tijarah, yang pada hakikatnya tidak hanya bersifat material dan hanya bertujuan mencari keuntungan material semata, tetapi juga bersifat immaterial. Karena aktivitas dalam berbisnis ini tidak hanya melibatkan hubungan antara sesama manusia saja namun juga hubungan antara manusia dengan Allah SWT. Dengan begitu berbisnis harus dilakukan dengan ketelitian dan kecermatan dalam proses administrasi dan perjanjian yang ada didalam bisnis tidak boleh dilakukan dengan cara penipuan dan kebohogan hanya demi memperoleh keuntugan.
Dalam dunia bisnis saat ini tidak hanya kaum pria saja yang sukses menjalankan bisnis, kaum Wanita pun saat ini banyak yang sukses dalam menjalankan dunia bisnis. Pandangan islam dalam muslimah yang berbisnis sangat memberikan nilai yang positif, hal ini membuat muslimah semakin termotivasi dan bersemangat dalam menjalankan bisnis. Letak keistimewaan Wanita dalam berbisnis bukan hanya sekedar duniawi namun juga memberikan kedudukan yang membanggakan untuk para muslimah yang turut membanting tulang demi menghidupi keluarganya.

Sebenarnya pada jaman Rasulullah SAW dahulu sudah terdapat Wanita yang sukses dalam berbisnis.

1) Jurnal ini merupakan bagian skripsi dari Sesha Ayu Permatasari, NIM : 041114167, yang diuji pada tanggal 7 Agustus 2015 
Wanita ini adalah Siti Khadijah yang tidak lain adalah istri pertama dari Rasulullah Muhammad SAW. Beliau adalah salah satu contoh sukses Wanita yang sukses berbisnis dengan cara berbisnis secara ekonomi islam. Dari kesuksesan Siti Khadijah sebagai Wanita yang berbisnis tanpa pernah melalaikan kewajibannya sebagai ibu dan seorang istri maka Allah SWT tidak pernah melarang Wanita muslim untuk berbisnis. Berbisnis dalam islam tidak hanya saja harus halal dari segi modal dan bagaimana cara kita berbisnis tetapi juga garus desertai niat yang baik dan berbisnis karena Allah SWT. Karena dengan begitu rezeki yang kita terima akan membawa berkah dan kita juga perlu memebelanjakan harta kita di jalan Allah SWT.

Dari cerita Siti Khadijah yang sukses sebagai seorang pelaku bisnis juga sebagai seorang istri dan seorang ibu membuat muslimah saat ini termotivasi untuk berbisnis. Dimasa saat ini banyak juga contoh Wanita muslim yang sukses dalam berwirausaha, misalnya saja Sheikha Hanadi binti Nasser Al Thani dia adalah salah satu pengusaha property yang sukses di Qatar, beliau adalah CEO dari proyek AL Waab City Real Estate dan dia juga adalah seorang Banker dan juga investor. Selain jabatanya menjadi CEO di proyek Al Waab City Real Estate dia juga adalah penasihat khusus di Standart Chartered Bank. Selain memiliki karier yang gemilang Wanita muslim ini juga mempunyai paras wajah yang sangat cantik. Sedangkan pada era saat ini tidak banyak Wanita yang sukses sebagai seorang banker, apalagi Wanita itu adalah Wanita muslimah. Namun Sheikha Hanadi Binti Nasser Al Thani ini dapat membuktikan bahwa ia bisa sukses asal mau berusaha dan niatnya untuk berusaha adalah beribadah dan mencari ridha Allah.

Wanita-Wanita ini telah berhasil dalam pekerjaannya namun sebagai Wanita tidak boleh lupa dengan kodratnya meskipun mereka sukses dalam bidang usahanya namun tugas utama mereka yang utama adalah tetap bagaimana mereka mendidik anakanaknya agar menjadi cerdas dan berguna bagi orang lain dan berakhlak yang baik. sehingga Wanita muslim yang benar-benar sukses adalah Wanita muslim yang berhasil menjalankan kedua perannya yaitu sebagai ibu rumah tangga dan sebagai pengusaha muslim yang baik, dengan begitu perpempuan muslim ini tidak hanya membantu menggerakkan perekonomian keluarga dan sukses meraih mimpinya namun juga melahirkan generasi penerus yang cerdas dan berakhlak baik. hal ini telah di contohkan oleh Siti Khadijah, beliau adalah pedagang Wanita yang sangat kaya dan sukses namun ketika beliau berada di tengah keluarganya beliau tetap seorang ibu yang hangat kepada anak-anaknya dan melahirkan anak-anak yang berakhlak baik dan cerdas juga selalu taat kepada suaminya.

Islam memberikan pandangan tersendiri terhadap wanita yang ingin 
berdagang seperti halnya Siti Khadijah. Pada masa kini, berdagang juga dapat diidentikkan dengan berwirausaha atau berbisnis. Benschop (2009) dalam penelitiannya yang berjudul "Muslim businesswomen doing boundary work: The negotiation of Islam, gender and ethnicity within entrepreneurial contexts" menjelaskan bahwa pekerjaan seorang Wanita berkaitan dengan etnik dan agama yang dianut. Islam memberikan batasan-batasan yang harus diimplementasikan di atas kebudayaan suatu daerah. Hasil penelitian ini menjelaskan bahwa aturan-aturan dalam Islam, yang dijelaskan melalui Al-Quran maupun Hadist, harus lebih diutamakan melebihi kebudayaan yang di anut di suatu daerah.

Wanita yang memutuskan untuk berwirausaha, tentunya memiliki motif tertentu, yang bisa jadi berbeda untuk setiap orang dan juga di setiap daerah. Tentunya motif seorang Wanita dalam berwirausaha berbeda-beda sesuai daerahnya, karena setiap daerah memiliki karakteristik yang unik, seperti Wanita pebisnis yang tergabung di IWAPI Surabaya.

Selain motif, Wanita yang memilih berwirausaha pasti akan mengalami banyak tantangan, berkaitan dengan identitas mereka sebagai ibu rumah tangga, dan juga berkaitan dengan agama dan kebudayaan setempat. Alam (2012) menjelaskan hambatan yang sering dialami Wanita pebisnis adalah kondisi stres karena pekerjaan yang berat, kekurangmampuan untuk menentukan lokasi usaha, kekurangmampuan untuk mengelola waktu dengan keluarga, kekurangmampuan untuk mendapatkan pinjaman keuangan, terjadinya ketidakseimbangan antara kelvarga dan bisnis, kurang memiliki pendamping/ guru bisnis, kurang memiliki akses informasi, tidak cukup dukungan dari keluarga, dan prasangka masyarakat setempat terhadap Wanita yang berbisnis. Hambatan-hambatan tersebut dapat berdampak terhadap kelancaran seorang Wanita dalam menjalankan bisnisnya.

Berdasarkan fenomena-fenomena yang telah dijelaskan di atas, peneliti tertarik untuk meneliti bagaimana perilaku bisnis Wanita muslim yang telah berkeluarga di IWAPI Surabaya, yang terdiri dari motivasi bisnis, perilaku bisnis, dan tanggungjawab sebagai individu, istri, ibu, dan anggota IWAPI.

\section{LANDASAN TEORI}

\section{Hakikat Wanita Dalam Islam}

Solich (2012) menjelaskan bahwa Wanita muslimah sesungguhnya memiliki kedudukan yang tinggi dalam Islam dan sangat berpengaruh pada kehidupan setiap manusia. Diantara kedudukan tinggi tersebut adalah:

1. Wanita Sebagai Hamba Allah

Seorang Wanita mempunyai tanggung jawab yang sama dengan laki-laki delam kedudukannya sebgai hamba Allah, yakni sama-sama mempunyai kewajiban untuk mengabdikan diri kepada Allah SWT. 
2. Wanita Sebagai Istri

Seorang istri adalah sahabat bagi suaminya. Di dalamnya melekat segala kewajiban yang harus dilaksanakan kepada suaminya. Seorang istri harus mampu menjaga rahasia dan harta benda suaminya sebagai amanah yang kelak akan dimintai pertanggungjawaban di hadapan Allah. Seorang istri seyogyanya harus mempunyai keahlian dan ketrampilan, seperti memasak, penataan rumah, menata penampilan, dan cerdas dalam ilmu pengetahuan masalah kesehatan dan pengaturan keuangan. Istri adalah menteri keuangan terbaik dalam rumah tangga.

3. Wanita Sebagai lbu

Dijelaskan dalam Al-Quran betapa pentingnya peran Wanita sebagai ibu, istri, saudara Wanita, maupun sebagai anak yang berbakti. Demikian juga dengan hak-hak dan kewajibannya. Peran Wanita adakalanya sangat berat, bahkan bisa sampai semisal harus menanggung beban-beban yang semestinya dipikul oleh laki-laki. Oleh karena itu, menjadi suatu keharusan bagi kita untuk selalu berterimasih kepada ibu, berbakti, dan bersikap baik padanya. Posisi ibu terhadap anak-anaknya lebih didahulukan dari ayah.

"Al-ummu madrosatul
uulaa", ibu adalah madrasah
pertama. Peran tersebut adalah

dalam kpasitasnya membangun keluarga dan masyarakat yang shalih selama ia berada pada jalan AlQuran an sunnah Nabi yang akan menjauhkan setiap muslim dan mulimah dari kesesatan segala hal. Ibu adalah pembuka ilmu pertama bagianaknya. Darinya, anak pertama kali belajar, sehingga dia mempunyai pengaruh yang besardalam tumbuh kembang dan pola pikir anakanaknya dalam memnina generasi masa depan yang baik. Wanita adalah tiang negara.

4. Wanita Sebagai Anggota Masyarakat Wanita menjadi bagian dari sebuah masyarakat. Dia memiliki tanggung jawab terhadap lingkungan serta kondisi sosialnya. Posisi tersebut menuntut peranan seorang Wanita tidak hanya dalam keadaan privat, tetapi juga kehidupan politik. Hal tersebut saling mengakomodasi dalam menjalankan tanggung jawabamar ma'ruf nahi munkar. Wanita harus cakap dalam mengambil langkah-langkah praktis yang dibutuhkan dalam menghadapi perubahan di tengah-tengah masyarakatnya. Wanita juga dibutuhkan dalam kiprahnya untk berdakwah di tengah masyarakat, agar kaum Wanita memiliki pengetahuan Islam dan umum yang mumpuni

Arfan (2009) menjelaskan bahwa di dalam Al-Qur'an menerangkan tipe ideal Wanita Islam (muslimah) sebagai pribadi 
yang memiliki kemandirian dalam berbagai bidang kehidupan, yaitu:

1. Pertama, muslimah harus memiliki kemandirian politik

2. Kedua, muslimah harus memiliki keberanian dalam bidang ekonomi, seperti figur Wanita pengelola peternakan dalam kisah Nabi Musa di Madyan

3. Ketiga, muslimah harus memiliki sifat kemandirian individual, misalnya kemandirian dalam menentukan pilihan pribadi yang diyakini kebenarannya sekalipun berhadapan dengan suami bagi Wanita yang sudah menikah.

\section{Hak-Hak Wanita}

Beberapa hak yang dimiliki oleh kaum Wanita menurut pandangan ajaran Islam.

1. Hak-hak Kemanusiaan

Diantara hak-hak kemanusiaan antara lain hak hidup, hak mendapat kemuliaan, hak kesetaraan dengan laki-laki, dan hak mengemukakan pendapat dan musyawarah.

2. Hak-hak Ekonomi

Hak-hak ekonomi Wanita meliputi hak kepemilikan dan pengelolaan. Islam memberikan kebebasan terhadap Wanita dalam hal pengelolaan dan urusannya dalam harta, perdagangan, akad jual beli, persewaan, perserikatan, dan sebagainya. Wanita juga diperbolehkan untuk menetapkan mahar yang akan diterima dari calon suaminya.
3. Hak-hak Sosial

Diantara hak-hak tersebut antara lain mendapatkan perlakuan baik, memilih suami, mendapatkan nafkah, mendapatkan warisan, mendapatkan mahar, meminta cerai, mendapatkan pendidikan dan pengajaran, dan beraktifitas.

4. Hak-hak Konstitusi
a. Bidang Politik
b. Bidang hukum

\section{Pandangan Islam Terhadap Wanita Karir}

Perbincangan berkenaan dengan hukum ibu rumah tangga yang bekerja dapat dilihat dari sudut hukum wanita bekerja di luar rumah. Berhubung dengan masalah ini, terdapat dua pandangan dalam kalangan ulama.

1. Pandangan pertama dipelopori oleh sebagian besar ulama terutama ulama kontemporer, yang berpendapat isteri termasuk dalam kalangan kaum wanita yang mempunyai sifat-sifat kewanitaan sebagaimana wanita-wanita lain. Wanita juga seperti kaum lelaki yang boleh berfikir, bekerja dan bertindak mengikut kemauannya karena mereka tergolong di kalangan manusia. Di samping itu juga, Allah S.W.T. telah menjelaskan bahawa fungsi kaum wanita adalah untuk memenuhi keperluan hidup kaum lelaki. Mereka saling memerlukan di antara satu sama lain. Sumber pendapat ini adalah Surah al-Qasas (28:23) dan kaedah Figh, yaity syariat Islam tidak membenarkan siapapun 
mengharamkan sesuatu perkara kecuali dia berpandukan kepada suatu nas dan dalil yang sah dari segi kesabitannya.

2. Pandangan kedua mengatakan wanita atau isteri tidak dibenarkan bekerja di luar rumah. Ini karena tempat yang sesuai bagi kaum wanita adalah di rumah. Rumah adalah tempat untuk mereka menguruskan hal-hal rumah tangga dan mendidik anak-anak. Sekiranya mereka ikut serta bersama-sama kaum lelaki keluar melibatkan diri dalam pekerjaan, maka ia boleh menjelaskan hubungan kasih sayang dan pendidikan mereka terhadap anak-anak.

\section{Syarat-Syarat dan Etika Menjadi Wanita} Karir

Menurut Islam, kerja yang dilakukan oleh wanita atau isteri hendaklah memenuhi beberapa etika kerja sebagaimana yang telah ditetapkan oleh Syarak. Di antaranya sebagaimana berikut:

a. Pekerjaan yang sesuai dengan fitrah dan kemampuan wanita, dilihat dari sudut pandang syariat, jasmani, maupun rohani.

b. Menjaga adab-adab sebagai wanita Islam, yaitu apabila keluar bekerja memperhatikan akhlak dalam penggunaan perhiasan, percakapan, dan tingkah laku. Adab ini diantaranya menutup aurat, tidak memakai wangi-wangian yang membangkitkan birahi seseorang, tidak bergaul bebas atau berkhalwat dengan kaum lelaki, dan meminta keizinan dari suami dan sebagainya.

c. Tidak mengkesampingkan kewajipan lain seperti kewajipan terhadap suami dan anak-anak. Kewajipan terhadap keduanya lebih utama dibandingkan bekerja. Seorang isteri hendaklah bijaksana dalam membagi waktu dalam menunaikan tanggungjawabnya bersama suami dan anak-anak agar kesejahteraan dan keharmonian rumahtangga dan kelvarga dapat dicapai.

\section{Perspektif Wanita Pengusaha dalam Hukum Islam}

Wanita muslimah yang menjadi pengusaha dalam konteks kehidupan era globalisasi pada prinsipnya adalah diperbolehkan (al-ibahah) sepanjang tidak menyalahi tata aturan (normanorma agama) yang ditetapkan alQur'an dan hadis. Sebagaimana kaidah fiqhiyah menegaskan bahwa, pada prinsipnya hukum asal pada sesuatu itu dibolehkan sehingga terdapat bukti (dalil) lain yang melarangnya.

Sebaliknya, wanita muslimah menjadi pengusaha itu dilarang (altahrim) apabila melanggar norma-norma agama yang ditetapkan al-Qur'an dan hadis, di samping tidak mampu menjaga kesucian, kehormatan dan martabatnya. Kaidah fighiyah menegaskan bahwa pada prinsipnya hukum asal pada sesuatu itu dilarang sehingga terdapat bukti (dalil) lain yang membolehkannya. 
Wanita muslimah menjadi pengusaha adalah diperbolehkan apabila:

a. Sudah sanggup bekerja sesuai dengan kodrat wanita dan keahlian (skill) yang dimilikinya.

b. Apabila penghasilan suami tidak mencukupi kebutuhan rumah tangganya, maka boleh isteri membantu suami dalam mencari rizki yang berkaitan dengan usaha suaminya. Seperti ditegaskan oleh Ali Alhamidy bahwa "katakanlah kesungguhanmu berusaha membantu suamimu dalam segala usaha yang bertalian dengan kepentingan pekerjaannya."

c. Apabila dalam kondisi sangat memaksa, misalnya wanita (isteri) yang ditinggal wafat oleh suaminya atau disebabkan perceraian demi untuk memenuhi kebutuhan hidup anak-anak dalam rumah tangganya, maka dia boleh berusaha dengan bekerja keras (usaha di jalan Allah) dengan menjadi karyawan, distributor atau menjadi pengusaha sehingga terpenuhi hajat hidupnya.

\section{Perilaku Bisnis}

Perilaku adalah tindakan atau aktivitas dari manusi itu sendiri yang mempunyai bentangan yang sangat luas antara lain : berjalan, berbicara, menangis, tertawa, bekerja, kuliah, menulis, membaca, dan sebagainya. Dari uraian dapat disimpulakn bahwa yang dimaksud perilaku manusia adalah semua kegiatan atau aktivitas manusia, baik yang diamati langsung, maupun yang tidak diamati langsusng oleh pihak luar (Notoatmodjo.2003:144).

Menurut Skinner, seperti yang di kutip oleh Notoadmodjo (2003:113), merumuskan bahwa perilaku merupakan respon atau reaksi seseorang terhadap stimulus atau rangsangan dari luar.

Sedangkan bisnis merupakan pertukaran barang atau jasa dengan saling menguntungkan atau saling memberikan manfaat (anoraga,2007). Oleh karenanya, perilaku bisnis adalah aktivitas manusia atau reaksi tentang aktivitas pertukaran barang atau jasa yang saling menguntungkan dan memberikan manfaat.

\section{Motivasi Bisnis}

Alam (2012) dalam penelitiannya yang berjudul "An Exploratory Study of Women Entrepreneurs in Malaysia: Motivation and Problems", menyimpulkan bahwa motivasi seorang Wanita untuk berbisnis adalah sebagai berikut:

1. Menginginkan kebebasan yang lebih luas dalam beraktivitas dan bekerja

2. Keinginan keluar dari pekerjaan yang menuntut waktu yang tidak fleksibel

3. Keinginan untuk menjadi bos bagi diri sendiri

4. Suka membuat ide atau inovasi

5. Keinginan untuk mendapatkan penghasilan yang lebih banyak

6. Keinginan untuk mendapatkan laba dari setiap aktivitas bisnis yang dijalani 
7. Suka dengan ide-ide yang berkaitan dengan teknologi

8. Keinginan untuk mengembangkan dan menggabungkan hobi dengan bisnis

9. Menyukai tantangan

10. Merasa tidak puas dengan pekerjaan yang sebelumnya

11. Keinginan untuk mendapatkan status sosial yang lebih baik dalam masyarakat

12. Keinginan untuk mencontoh seseorang yang saya kagumi dalam berbisnis

13. Keinginan untuk mendapatkan lebih banyak rasa hormat apabila bekerja untuk diri sendiri

14. Keinginan untuk melanjutkan tradisi kelvarga yang sudah berjalan lama

15. Keinginan untuk memimpin dan memotivasi orang lain

\section{Hambatan Yang Dialami}

Hambatan yang paling sering terjadi pada seorang wanita yang memiliki bisnis adalah terjadinya konflik antara keluarga dengan pekerjaannya/ bisnisnya, yang didefinisikan sebagai konflik kerja-keluarga (work-family conflict). Konflik kerja-keluarga (workfamily conflict) adalah konflik yang terjadi pada individu akibat menanggung peran ganda, baik dalam pekerjaan (work) maupun keluarga (family), di mana karena waktu dan perhatian terlalu tercurah pada satu peran saja di antaranya (biasanya pada peran dalam dunia kerja), sehingga tuntutan peran lain (dalam keluarga) tidak bisa dipenuhi secara optimal.

Alam (2012) dalam penelitiannya yang berjudul "An Exploratory Study of Women Entrepreneurs in Malaysia: Motivation and Problems", menyimpulkan bahwa hambatan seorang Wanita dalam berbisnis adalah sebagai berikut:

1. Perasaan stres karena tanggungjawab yang berat

2. Ketidakmampuan untuk memperoleh lokasi atau tempat usaha

3. Ketidakmampuan untuk menghabiskan cukup waktu bersama keluarga

4. Ketidakmampuan untuk memperoleh pinjaman keuangan dari sumber pendanaan (Bank atau yang lain)

5. Ketidakmampuan untuk memperoleh pembiayaan untuk pembelian peralatan

6. Kehidupan keluarga dan bisnis yang tidak seimbang

7. Ketidakmampuan untuk menemukan saran dari ahli sebagai mentor bisnis dan teman diskusi

8. Ketidakmampuan untuk mengakses sumber daya informasi

9. Tidak cukup dukungan dari keluarga

10. Masih adanya stigma yang negatif oleh masyarakat sekitar dalam memandang wanita yang berbisnis

\section{Pembentukan Karakter Pengusaha Berdasarkan 4 Sifat Nabi}

Tujuan utama dari tugas kenabian adalah untuk mengajarkan kepada manusia bagaimana cara mendapatkan kebahagian dan keselamatan, baik di 
dunia maupun di akhirat (Moedjiono, 2002: 34). Nabi dan rasul sebelum diangkat menjadi nabi memiliki ciri-ciri kenabian (nubuwwah) yang disebut juga sebagai irkhash. Secara khusus, terdapat empat sifat para nabi dan rasul Allah Swt. terutama yang diwarisi oleh Nabi Muhammad saw. sebagaimana diungkap oleh Moejiono (2002: 34) seperti berikut:

1. Shiddiq (benar).

Siddiq merupakan sifat Nabi yang memiliki arti punya niat yang benar, sungguh-sungguh, memiliki ucapan yang selaran dengan tidakan, jujur, dan menepati janji. Shiddiq berarti benar dalam hal perkataan dan perbuatan. Dalam keseharian, seseorang yang memiliki karakter ini akan konsisten pada kebenaran, baik dalam ucapan, sikap maupun perilaku.

2. Amanah (terpercaya).

Amanah merupakan sifat Nabi yang memiliki arti dapat dipercaya atau memiliki kredibilitas. Kredibilitas tersebut mencakup kualitas secara moral dan kualitas secara keahlian profesional. Dalam keseharian, seseorang yang memiliki karakter ini ia berlaku jujur, memiliki moral yang baik, komitmen pada tugas dan kewajiban.

3. Fathanah (cerdas/bijaksana).

Fathonah merupakan sifat Nabi yang memiliki arti kecerdasan. Cerdas dalam menyelesaikan setiap permasalahan yang dihadapi, dengan cara-cara yang tidak melanggar norma agama dan norma sosial. Seseorang yang memiliki karakter ini ia memiliki penalaran yang baik, kearifan, bijak dalam keputusan, kemampuan mengambil berbagai realitas (hikmah) dari fenomena yang dihadapi.

4. Tabligh (menyampaikan).

Tabligh merupakan sifat Nabi yang memiliki arti kemampuan komunikasi yang baik. Tabligh mencakup tiga hal, yaitu: (1) komunikasi yang baik dalam menyampaikan informasi, berita, dan gagasan (2) kemampuan dalam memilih bahasa yang jelas dan mudah dipahami, dan kemampuan menentukan strategi komunikasi yang tepat sesuai pasar yang dilayani. Seseorang yang memiliki karakter ini ia menyampaikan kebijakan secara terbuka, melibatkan orang lain dalam pengambilan keputusan dan mempunyai sikap terbuka (transparan).

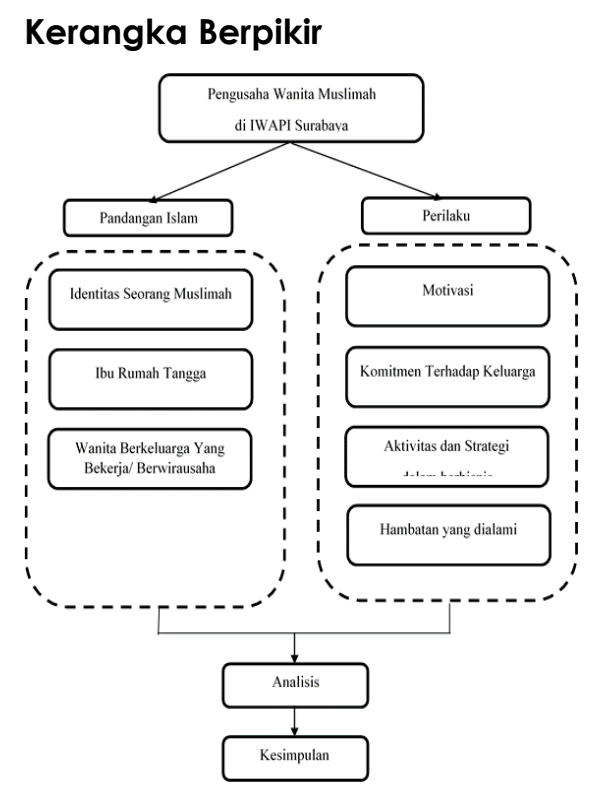

Gambar 1. Kerangka Berpikir 


\section{METODE PENELITIAN}

\section{Pendekatan Penelitian}

Pendekatan yang digunakan dalam penelitian ini adalah pendekatan studi kasus. Penelitian studi kasus menurut Basuki (2006) adalah kajian mendalam tentang peristiwa, lingkungan, dan situasi tertentu yang memungkinkan mengungkapkan atau memahami sesuatu hal. Pada penelitian ini, peneliti akan mengungkapkan secara mendalam bagaimana perilaku bisnis Wanita muslim yang telah berkeluarga di IWAPI Surabaya, dilihat dari motivasi bisnis, perilaku bisnis, dan tanggungjawab.

\section{Ruang Lingkup Penelitian}

Ruang lingkup penelitian dibatasi oleh perilaku bisnis Wanita muslim yang tergabung dalam IWAPI (Ikatan Wanita Pengusaha Islam) yang telah berkeluarga di kota Surabaya.

\section{Obyek dan Subyek Penelitian}

Objek yang digunakan di dalam penelitian ini adalah perilaku pengusaha Wanita muslim, sedangkan subyek penelitian adalah pengusaha Wanita muslim yang telah berkeluarga dan tergabung di IWAPI Surabaya lebih dari satu tahun. Penelitian ini akan dilakukan di IWAPI Surabaya. Populasi sasaran adalah semua anggota IWAPI yang telah berkeluarga dan telah menjadi anggota minimal dalam satu tahun terakhir. Berdasarkan wawancara peneliti dengan ketua IWAPI Surabaya, menginformasikan bahwa jumlah anggota IWAPI yang telah berkelvarga dan tercatat sebagai anggota minimal setahun berjumlah 35 orang.

\section{Narasumber}

Pada penelitian ini, yang menjadi narasumber utama adalah pengusaha Wanita muslim yang telah berkeluarga di IWAPI Surabaya. Narasumber yang digunakan dalam peneliyian ini berjumlah 5 orang, yang dipilih berdasarkan kriteria:

a. Wanita muslimah

b. Sudah menjadi pengusaha lebih dari 5 tahun

c. Tergabung di keanggotaan IWAPI Surabaya lebih dari 1 tahun

d. Bersedia diwawancara dan menjadi narasumber dalam penelitian ini

\section{Jenis dan Sumber Data}

Sumber data merupakan hal yang paling penting di dalam proses penelitian. Sumber data yang relevan merupakan cerminan dari integritas informasi yang ada di dalam penelitian. Pada penelitian ini, sumber data yang digunakan adalah:

1. Data primer

2. Data sekunder

\section{Teknik Pengumpulan Data}

Teknik pengumpulan data yang dilakukan di dalam penelitian ini adalah sebagai berikut:

a. Wawancara mendalam (in-depth interview)

b. Observasi Partisipan

C. Studi Dokumentasi

\section{Teknik Analisis Data}

Pada penelitian ini, teknik analisa data yang digunakan adalah teknik analisa kualitatif model Miles and 
Huberman. Aktivitas analisis data kualitatif yang terdapat pada model Miles and Huberman adalah:

a. Reduksi Data (Data Reduction)

Reduksi data yang digunakan adalah dengan mencatat dan memilih, serta merangkum data-data yang diperlukan di dalam proses penelitian, yang berkaitan dengan Pandangan Islam terhadap Wanita yang berbisnis, serta bagaimana perilaku bisnis Wanita muslim dari aspek motivasi, komitmen terhadap kelvarga, aktivitas dan strategi, serta hambatan yang dialami.

b. Penyajian Data (Data Display)

Setelah melakukan reduksi data, tahap selanjutnya yang perlu dilakukan yaitu melakukan penyajian data. Pada penelitian ini, penyajian data merupakan hasil dari reduksi data berupa tulisan dan akan disajikan dalam bentuk teks yang bersifat naratif, sehingga mudah dipahami di dalam proses penelitian ini.

c. Verifikasi (Conclusion Drawing)

Langkah ke tiga dalam analisis data kualitatif menurut Miles and Huberman adalah penarikan kesimpulan dan verifikasi. Pada penelitian ini, penarikan kesimpulan berasal dari hasil reduksi dan penyajian data yang isinya masih bersifat sementara dan proses verifikasi data dilakukan dengan cara membandingkan dengan data-data yang valid, yaitu dengan membandingkan dengan hasil teori atau kembali di lapangan untuk mengumpulkan data kembali yang dimungkinkan akan memperoleh bukti-bukti kuat lain yang dapat mengubah hasil kesimpulan sementara yang diambil.

\section{HASIL dan PEMBAHASAN ANALISIS DATA}

\section{Motivasi Bisnis Dalam Islam}

Hukum ibu rumah tangga yang bekerja atau berbisnis dilihat dari sudut pandang Islam adalah boleh. Pandangan ini disepakati oleh sebagian besar Ulama dengan berlandaskan Al-Quran Surah Ali 'Imran (3: 195) dan Surah al-Qasas (28:23). Selain itu, berdasarkan kaedah Figh, syariat Islam tidak membenarkan siapapun mengharamkan sesuatu perkara kecuali dia berpandukan kepada suatu nas dan dalil yang sah dari segi kesabitannya. Terlepas dari bolehnya seorang ibu rumah tangga untuk bekerja atau berbisnis, Islam mengatur bahwa kerja yang dilakukan oleh wanita atau isteri hendaklah memenuhi beberapa etika kerja sebagaimana yang telah ditetapkan oleh Syarak, diantaranya adalah sebagai berikut:

a. Pekerjaan yang sesuai dengan fitrah dan kemampuan wanita, dilihat dari sudut pandang syariat, jasmani, maupun rohani.

b. Menjaga adab-adab sebagai wanita Islam, yaitu apabila keluar bekerja memperhatikan akhlak dalam penggunaan perhiasan, percakapan, dan tingkah laku. 
Adab ini diantaranya menutup aurat, tidak memakai wangiwangian yang membangkitkan birahi seseorang, tidak bergaul bebas atau berkhalwat dengan kaum lelaki, dan meminta keizinan dari suami dan sebagainya.

c. Tidak mengkesampingkan kewajipan lain seperti kewajipan terhadap suami dan anak-anak. Kewajipan terhadap keduanya lebih utama dibandingkan bekerja, seorang isteri hendaklah bijaksana dalam membagi waktu dalam menunaikan tanggungjawabnya bersama suami dan anak-anak agar kesejahteraan dan keharmonian rumahtangga dan keluarga dapat dicapai.

Rasulullah sendiri menganjurkan setiap manusia untuk sukses, baik laki-laki maupun Wanita. Kesuksesan dapat dicapai terutama melalui perniagaan (perdagangan/ bisnis). Rahasia kesuksesan yang diterapkan oleh Rasulullah saw dalam perniagaan adalah (a) menjadikan Bekerja sebagai ladang menjemput syurga (b) menerap kejujuran dan kepercayaan (c) berfikir visioner, kreatif, dan siap menghadapi perubahan (d) memiliki planning dan goal setting yang jelas (e) pintar mempromosikan diri (f) menggaji karyawan sebelum keringatnya mengering (g) bekerja dengan cerdas (h) mengutamakan sinergi dengan orang lain untuk bersama-sama dalam memajukan bisnis (i) pandai bersyukur dan berucap terima kasih, dan (j) berbisnis dengan Cinta.

\section{Motivasi Bisnis Anggota IWAPI Kota Surabaya \\ Motivasi bisnis Wanita muslim yang telah berkeluarga di IWAPI Surabaya adalah keinginan untuk memiliki kebebasan beraktivitas, keinginan keluar dari pekerjaan sebelumnya yang memiliki waktu yang tidak fleksibel, adanya keinginan untuk menjadi bos bagi dirinya sendiri dengan penghasilan yang lebih banyak dari laba yang dihasilkan, bisa menyalurkan ide-ide kreatif dari diri sendiri yang berkaitan dengan teknologi sehingga bisa mendapatkan status sosial dan penghormatan dari masyarakat yang jauh lebih baik, adanya keinginan untuk bisa memimpin, serta memotivasi orang lain karena sebagai penyuka tantangan.}

\section{Aktivitas Bisnis}

Perilaku bisnis Wanita muslim yang telah berkeluarga di IWAPI Surabaya akan dikaitkan dengan 4 sifat Nabi. Implementasi sifat siddiq oleh informan pada penelitian ini meliputi menjaga kepercayaan klien, menjaga kejujuran, pelayanan tepat waktu, serta adanya jaminan keamanan produk yang dijual. Implementasi sifat amanah juga penting pada bisnis yang dijalani, meliputi menjaga kepercayaan baik kepada klien maupun karyawan, menjaga kualitas pelayanan, serta menjalankan pekerjaan sesuai permintaan spesifikasi dari klien. Hasil implementasi sifat tabligh oleh informan juga penting yang meliputi menyamakan visi antara pemilik dengan 
karyawan, visualisasi menjadi pelanggan atau dalam ilmu pemasaran dikenal dengan nama ghost shopping, dan memberikan informasi yang sebenarnya mengenai kondisi produk atau layanan yang dijual. Sedangkan implementasi sifat fathonah juga penting yang meliputi edukasi kemampuan komunikasi karyawan, selalu bersyukur, dan cerdas dalam mengkomunikasikan barang atau layanan yang dijual.

\section{Hambatan Wanita Yang Berbisnis}

Hambatan yang dialami informan terutama adanya perasaan stres karena menanggung tanggungjawab yang berat antara mengurus bisnis dan mengurus keluarga. Solusi yang dilakukan informan untuk mengatasi stres tersebut meliputi manajemen waktu yang baik, pengaturan keuangan secara disiplin dengan memisahkan pencatatan keuangan bisnis dan rumah tangga, selalu menjaga komunikasi dengan keluarga, menempatkan bisnis di rumah, serta pemanfaatan teknologi untuk menunjang kemudahan dalam aktivitas bisnis.

\section{Tanggungjawab}

Tanggungjawab wanita sebagai seorang individu adalah mengharuskan untuk dapat menyeimbangkan waktu antara bisnis dan ibadah, harus ada bimbingan rohani dari ustadz, serta selalu berdoa dan berusaha yang dapat membuat pikiran menjadi tenang, dengan pikiran tenang, bisnis dapat dikelola dengan baik. Selain tanggungjawab individu, seorang Wanita juga memiliki tanggungjawab sebagai seorang istri \& ibu rumah tangga. Istri adalah sahabat bagi suaminya, didalamnya melekat segala kewajiban, diantaranya menjaga martabat, harta benda, amanah, keterampilan rumah tangga, merias diri, cerdas dalam ilmu pengetahuan, dan pengaturan keuangan. Selain tanggungjawab individu, istri, dan ibu rumah tangga, Wanita yang menjadi informan pada penelitian ini juga memiliki tanggungjawab sebagai anggota IWAPI. Seorang Wanita juga harus memiliki kemandirian secara politik dan kemandirian dalam ekonomi, ini dilakukan salah satunya dengan menjadi anggota IWAPI dalam dalam visinya diantaranya bertujuan guna mensejahterakan umat, khususnya wanita baik secara potitik maupun ekonomi.

Motivasi Bisnis : Kelima informan mempunyai
motivasi ingin memiliki manajemen waktu yang lebih
fleksibel agar dapat leluasa mengatur waktu antara
berbisnis dan berumah tangga agar terciptanya
keseimbangan antara kedua nya sehingga dapat
sesuai dengan ajaran islam

Komitmen terhadap Keluarga : Kelima informan ini memiliki prinsip keluarga tetap menjadi prioritas utama meskipun mereka berbisnis. Dengan begitu kelima anggota IWAPI yang menjadi informan ini memilih meletakan kantor atau tempat usahanya didekat rumah mereka atau bahkan dirumah. Tujuannya adalah untuk dapat memantau keadaan dirumah tangga saat kelima informan ini berbisnis.

Dan sesibuk apapun aktivitas yang dimiliki kelima informan mereka tetap menjaga komunikasi yang baik kepada suami dan anak-anaknya. Hal ini bertujuan untuk meminimalisir adanya ketidaksinambungan dalam menerima suatu informas.

Aktivitas Bisnis dan Strategi Berbisnis : Dalam melaksanakan aktivitasnya dan strategi mereka 
dalam berbisnis selain mereka adalah tipe pengambil resiko dan menyukai tantangan. Strategi yang digunakan dalam berbisnis adalah dengan cara mengimplementasikan 4 sifat nabi dalam berbisnis yaitu :

- Jujur :

Kejujuran yang diterapkan oleh kelima informan ini dapat terlihat dari cara informan yang berbisnis sambal dan pakaian selalu berterus terang tentang kualitas barang yang dijualnya. Dan selalu berusaha memenuhi model seperti apa yang diinginkan klien. informan yang berbisnis di bidang kontraktor selalu berusaha memenuhi spek yang diingikan oleh klien. Sedangan kedua informan lainnya yang berbisnis di bidang jasa selalu berusaha jujur dalam mempromosikan.

- Amanah :

Dengan kejujuran yang telah dijalankan oleh kelima informan anggota IWAPI tersebut maka kepercayaan klien pun akan terjaga dengan baik.

- Fatonah :

Dalam aspek ini kelima informan mengimplementasikan dalam kondisi informan menemukan kelalaian yang dilakukan oleh informan atau dengan klien, kelima informan ini biasanya lebih memilih cara yang bijaksana dalam menyelesaikan masalah tersebut.

- Tabligh:

Kelima Informan melaksanaka aspek ini dilihat dari cara mereka memperlakukan konsumen yang ingin tahu tentang produk mereka. Misalnya saja informan yang memiliki klinik kecantikan ini sering berpura-pura sebagai konsumen untuk mengetahui sejauh mana konsumen puas dengan jasa yang dijualnya. Dengan begitu kedepannya dia bisa lebih baik dalam menginformasikan barang yang dijualnya

Hambatan yang dialami : Secara garis besar kelima informan ini mengaku hambatan yang sering dialami adalah perasaan tertekan yang dialami mereka saat konflik yang ada dalam pekerjaan dan rumah tangga timbul bersamaan. Biasanya problem ini dialami kelima konsumen saat asisten rumah tangga mereka tidak ada.

\section{KESIMPULAN}

Berdasarkan hasil analisis data dan pembahasan pada bab sebelumnya, dapat ditarik kesimpulan bahwa dalam penelitian kali ini kelima informan yang telah menjadi narasumber adalah kelima infoman anggota IWAPI tersebut dalam aktivitas dan strateginya dalam berbisnis telah menjalankan karakter yang harus dimiliki oleh pengusaha muslim yang diambil dari 4 sifat Nabi Muhammad SAW yaitu jujur, amanah, fatonah dan tabligh.

Dan secara garis besar kelima informan anggota IWAPI tersebut termotivasu dalam berbisnis karena ingin memiliki fleksibilitas waktu agar dapat mengatur antara keluarga dan berbisnis. sehingga berbisnis dan berumah tangga menjadi berjalan dengan seimbang agar sesuai dengan ajaran Islam.

Hambatan yang seringkali dialami oleh informan adalah perasaan tertekan aibat tanggung jawab atau konflik yang datang bersamaan antara bisnis dan urusan rumah tangga. Sehingga dengan adanya komitmen terhadap keluarga yaitu meletakan usaha yang lokasi usaha dekat dengan rumah dan mengkomunikasikan segala sesuatu dengan keluarga dapat meminimalisir hambatan yang terjadi. Karena hal ini telah menjadi tanggung jawab seorang wanita yang berprofesi sebagai pebisnis juga sebagai ibu rumah tangga dan yang aktif di IWAPI untuk menjaga keselarasan antara dunia bisnis, organisasi dan 
kelvarga. Namun kelima anggota IWAPI yang menjadi informan ini mempunyai prinsip bahwa urusan keluarga adalah prioritas utama bagi mereka.

Dari kesimpulan diatas, untuk peneliti selanjutnya untuk dapat ikut berpartisipasi dalam kegiatan IWAPI agar dapat lebih memahami secara psikologis dan meneliti perilaku bisnis dari aspek lainnya.

\section{DAFTAR PUSTAKA}

Alam. 2012. An Exploratory Study of Women Entrepreneurs in Malaysia: Motivation and Problems. Journal of Management Research Vol. 4 No. 1, p.282-297.

Arfan. 2009. Peran Wanita dalam pendidikan. Jurnal Musawa, Vol. 1 No. 1 hal. 75-82.

Basuki. 2006. Metode Penelitian. Jakarta: Pustaka Sinar Harapan.

Benschop. 2009. Muslim businesswomen doing boundary work: The negotiation of Islam, gender and ethnicity within entrepreneurial contexts. Journal of Human Relation, Vol. 62 No. 3 p. 403423.

Karim, Adiwarman. 2002. Ekonomi Islam, Suatu Kajian Ekonomi Makro. Jakarta: IIIT Indonesia.

Loh. 2013. Resilience and Economic Empowerment: A Qualitative Investigation Of Entrepreneurial Indonesian Women. Journal of Enterprising Culture, Vol. 21 No. 1 p. 107121.
Maimun. 2011. Wanita pengusaha menurut perspektif hukum Islam. Jurnal ASAS, Vol. 3 No. 1 hal. 1-12.

Malahayati. 2010. Rahasia Sukses Bisnis Rasulullah. Yogyakarta: Wisata Ruhani. Mauno, Kinnunen, dan Pyykko. 2005. Does Work-Family Conflict Mediate The Relationship Between Work-Family Culture and Self Reported Distress?: Evidence from Five Finnish Organizations". Journal of Occupational and Organizational Psychology, Vol.78 Part 4, p. 509.

Moejiono, Imam. 2002. Kepemimpinan dan Keorganisasian. Yogyakarta: UII Press.

Moleong. 2010. Metode Penelitian Kualitatif Edisi Revisi. Bandung: PT Remaja Rosdakarya.

Perrewe, Ralston, dan Fernandez. 1995. A Model Depicting The Relations Among Perceived Stressors, Role Conflict, and Organizational Commitment: A Comparative Analysis of Hongkong and The United States. Asia Pacific Journal of Management, Vol.12, Iss. 2, p.1.

Putra. 2011. Research and Development Penelitian dan Pengembangan: Suatu Pengantar. Jakarta: Raja Grafindo Persada.

Sekaran. 2006. Metodologi Penelitian untuk Bisnis, Edisi 4, Buku 1. Jakarta: Salemba Empat.

Siraj. 2012. Smoothing down ruffled feathers: the construction of Muslim women's feminine identities. Journal of Gender Studies, Vo. 21 No. 2 p. 185-199. 
Solich. 2012. Pemahaman Islam Tentang Keadilan Gender. Yogyakarta: Gama Media.

Sugiyono. 2013. Metode Penelitian Kuantitatif dan Kualitatif. Bandung: CV. Alfabeta.

Susanto. 2010. Konflik keluarga kerja pada wanita pengusaha. Jurnal Aset, Vol. 12 No. 1, hal: 75-85.

Tlaiss. 2013. Entrepreneurial motivations of women: Evidence from the United Arab Emirates. International Jurnal Small Business, Vol. 1 No. 1 p. 1-20. 